SASEC2015

Third Southern African Solar Energy Conference 11 - 13 May 2015

Kruger National Park, South Africa

\title{
SOLAR PANEL COOLING SYSTEM WITH HOLLOW FIBRES
}

\author{
Raudensky M.*, Astrouski I., Reppich M. and Schmidt M. \\ *Author for correspondence \\ Heat Transfer and Fluid Flow Laboratory, \\ Brno University of Technology, \\ Brno, 61669, \\ Czech Republic, \\ E-mail: raudensky@fme.vutbr.cz
}

\begin{abstract}
Solar panel overheating drastically reduces their efficiency and lifespan. This overheating is mainly associated with temperature fluctuations that occur under severe weather conditions. Overheating also has the potential to form electric arcs that can start to melt metal fixtures and burn away the module's insulating materials. The efficiency of electric solar panels is strongly dependent on temperature regime (especially in hot climates).

For this reason, the introduction of cheap and light watercooling, or a more general liquid-cooling system inside the solar panel, appears reasonable. Hollow fibre cooling systems consisting of plastic tubes of a small diameter (less than $1 \mathrm{~mm}$ ) are one possible and simple solution. Fibres placed inside solar panels can be glued or otherwise connected to the surface and coolant flowing through them provides efficient and uniform cooling of all photovoltaic cells. Hollow fibres have very thin walls (about $0.1 \mathrm{~mm}$ ) to transfer heat easily, and the system is light, compact and resistant to corrosion. Heat removed from the panel may be used for domestic or industrial needs or transferred to the atmosphere by cooling towers or dry-coolers.
\end{abstract}

\section{INTRODUCTION}

Green technologies are becoming more and more common. Thousands of photovoltaic (PV) panels and solar collectors have been installed all over the world. In 2013, $39 \mathrm{GW}$ of solar PV system installations were completed, with REN21's reporting growth of $139 \%$ in solar PV installation on a year-toyear basis [1]. The desire to increase the effectiveness of PV panels led to the development of so-called photovoltaic thermal hybrid solar collectors, sometimes known as PVT systems. These systems combine photovoltaic cells, converting electromagnetic radiation into electricity, with a solar thermal collector, capturing the remaining energy and removing waste heat from the PV module. The main advantage of this design is that coupling these two devices (PV system and solar collector) decreases the temperature of PV cells, thus increasing their electrical efficiency and operational life. Exergy analysis of solar thermal, photovoltaic, and hybrid photovoltaic thermal systems was conducted by Pathak et. all [2]. Results showed that PVT systems output has between $6.5 \%$ and $8.4 \%$ more exergy when compared to the purely PV systems and 4 times as much exergy as the pure solar thermal system.

Methods for cooling PV panels have been studied in several works. Akbarzadeh and Wadowski designed a solar PV panel cooling system based on a thermosyphon heat pipe [3]. It was found that the introduction of cooling prevents photovoltaic panels from overheating over $46^{\circ} \mathrm{C}$ over 4 hours, substantially increasing electrical output. Chaniotakis investigated cooling possibilities of both water and air as cooling agents for PVT panels. Water-based cooling was found to be more efficient but also more expensive. Moharram et al developed a water spraying system and mathematical model for cooling PV panels [5]. It was shown that the maximum allowable temperature, $45^{\circ} \mathrm{C}$, is a compromise temperature between the output energy from the PV panels and the energy needed for cooling. Different designs of PVT were analyzed in review by Ibrahim [6]. The paper presents the state-of-the-art on flat plate PVT collector classification, design and performance evaluations of water, air and combinations of water and/or air based systems. The author concluded that PVT solar collectors are a promising alternative system for low-energy applications and suggested several points for future investigations. Teo et al [7] investigated PV panel cooling by parallel arrays of ducts with an inlet/outlet attached to the back of the PV panel. It was found that without active cooling the temperature of the module was high and solar cells could only achieve an efficiency of 8 $9 \%$. Under active cooling conditions, the temperature dropped significantly, leading to an increase in the efficiency of solar cells to between $12 \%$ and $14 \%$.

Using polymeric hollow fibres for heat exchange applications was first proposed almost 10 years ago and several papers describing the hydraulic and thermal response of hollow fibres were published [8,9]. Hollow fibres are polymeric tubes 
with small diameters (about $1 \mathrm{~mm}$ ) that can be produced by an extrusion process using different plastics. The idea to use hollow fibres to cool PV modules is similar to the application of microcapillary films [10]. It was shown that such devices are effective heat exchangers that can remove heat from a heated surface for microelectronics cooling. These types of polymeric films were studied for solar collector applications [11]. It was reported that it is possible to fabricate all-plastic, low cost and low weight thermal collectors with all the advantages associated with a product made from one particular material (plastic). In the same manner, a cooling system of PVT panels was prepared from polypropylene hollow fibres and tested.

\section{EXPERIMENTAL DETAILS}

The cooling system (see Figure 1) was made from polypropylene (PP) hollow fibres. The fibres were uniformly distributed and the ends of the fibres were connected in PP inlet/outlet collectors. This cooling system is light, compact, non-corrosive and has a small internal volume, making it good for thermal control. Table 1 presents main parameters of the cooling system (for more details see [12]).

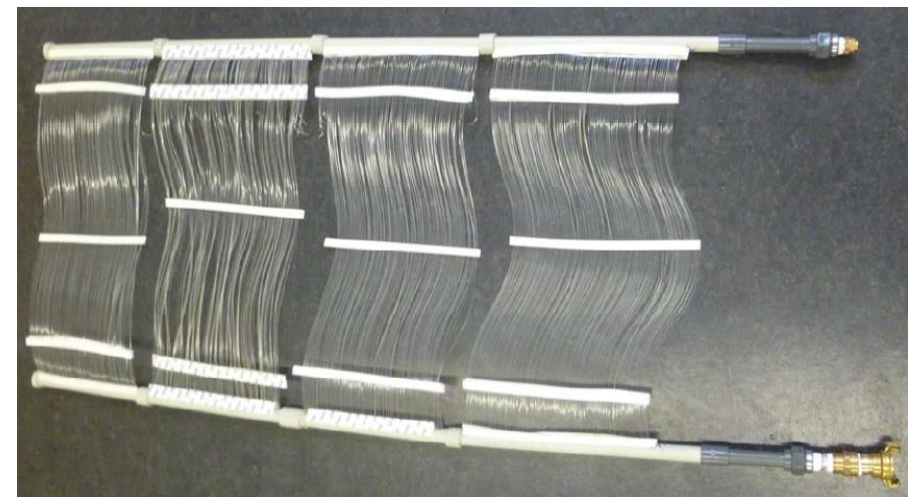

Figure 1 Heat exchanger before introduction into PV panel [12]

Table 1 Heat exchanger characteristics

\begin{tabular}{ccc}
\hline Parameter & value & Unit \\
\hline $\begin{array}{c}\text { Length of collectors with } \\
\text { fibres }\end{array}$ & 1000 & $\mathrm{~mm}$ \\
Width & 600 & $\mathrm{~mm}$ \\
$\begin{array}{c}\text { Inlet/outlet collector tube } \\
\text { diameter }\end{array}$ & $1 / 2$ & inch \\
Full number of fibres & 472 & - \\
Number of functional fibres & 425 & - \\
Mean fibre length & 568 & $\mathrm{~mm}$ \\
Fibre inner diameter & 0.63 & $\mathrm{~mm}$ \\
Fibre outer diameter & 0.83 & $\mathrm{~mm}$ \\
$\begin{array}{c}\text { Heat transfer area based on } \\
\text { full external surface of fibres }\end{array}$ & 0.63 & $\mathrm{~m}^{2}$ \\
Heat transfer area in touch & 12 & $\%$ \\
with PV back surface & 0.078 & $\mathrm{~m}^{2}$ \\
\hline
\end{tabular}

A monocrystalline silicon PV module was used to test the cooling system. The module was a gift to the University of Augsburg, so the exact origin and age of the module were unknown. Information about the module was taken from the label on the back of the module: STORM, model ND1325X674. The corresponding data are summarized in Table 2.

The cooling system was placed inside the module as shown in Figure 2. The contact between fibres and the back side of the PV module was created by pressure from insulation layer. To estimate the fibre heat transfer area in contact with the back surface of the PV, the following procedure was performed:

- fibres were painted with ink and the cooling system was placed inside the PV module

- the contact pressure was introduced and the module was mounted

- the module was dismounted and cooling system was removed

- the fibres' footprints were measured and used to calculate the heat transfer area (see Figure 3).

Table 2 PV module characteristics

\begin{tabular}{ccc}
\hline Parameter & value & Unit \\
\hline Rated Maximum power & 110 & $\mathrm{~W}$ \\
Rated voltage & 34.2 & $\mathrm{~V}$ \\
Rated current & 3.22 & $\mathrm{~A}$ \\
Open-circuit voltage & 42.8 & $\mathrm{~V}$ \\
Short-circuit current & 3.40 & $\mathrm{~A}$ \\
Maximum system voltage & 1000 & $\mathrm{~V}$ \\
Length & 1.32 & $\mathrm{~m}$ \\
Width & 0.67 & $\mathrm{~m}$ \\
\hline
\end{tabular}

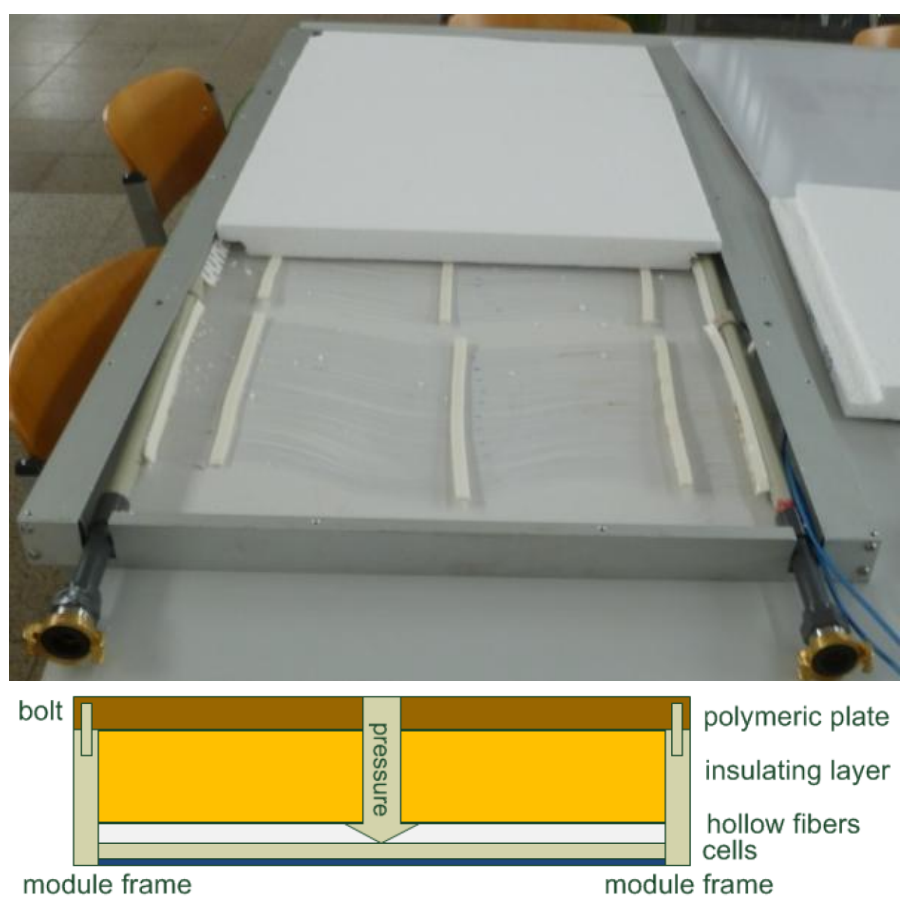

Figure 2 Heat exchanger placed inside the PV module [12]. 


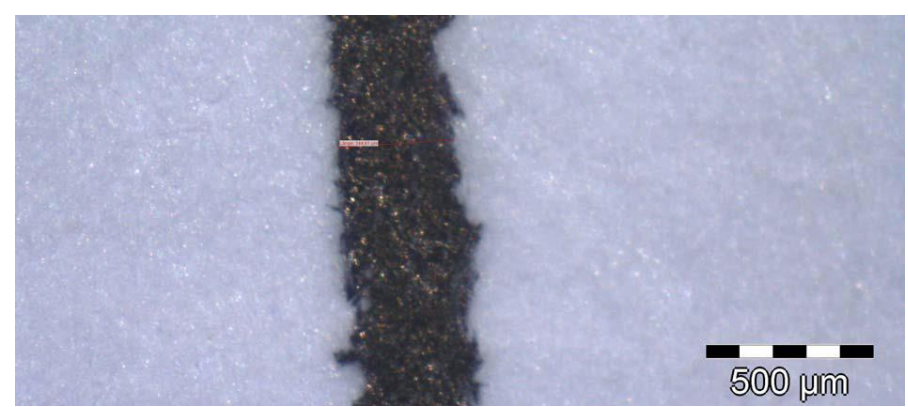

Figure 3 Example of the enlarged footprint of a fibre [12]

The cooling system was pressurized by water up to 3 bar gauge pressure to check for leaks in fittings and fibres. All damaged fibres which leaked during the test were eliminated. Moreover, coloured water (with the addition of ink) was used to identify fibres through which water could flow. Pressure drop of the module was controlled during all experiments, and the mean value of pressure drops was 0.4 bar for a $4.5 \mathrm{l} / \mathrm{min}$ flow rate.

Figure 4 shows the principal setup of the experimental stand. It consisted of a set of lamps ( 32 mercury vapour lamps and 27 halogen lamps) simulating solar radiation, cooling circuit equipment and measurement equipment. The radiation produced by the lamps had some differences from day to day and point to point. The average intensity of the lamps (24 measurements) was $802 \mathrm{~W} / \mathrm{m}^{2}$ taking $716 \mathrm{~W}$ for the entire surface of the module. The equipment measured the electrical and thermal characteristics of the module (for more details see [12]). In particular, the following parameters were recorded:

- ambient temperature

- intensity (at the edge of the test stand)

- current and voltage

- three surface temperatures on the top of the module

- four surface temperatures on the back of the module

- pressures, temperatures and the flow rate of water

This data was used to calculate performance, mean temperature on the top of the module, mean temperature on the back of the module and average module temperature. The positions of the temperature sensors were selected between the individual solar cells.

Three different types of tests were performed: the maximum-power-point test, the resistance test and the longterm test. To find the maximum-power-point the resistance was changed continuously using the rheostats from a minimum value to an infinite one. In contrast to the maximum-powerpoint test, the series of defined resistance values are approached in the resistance test. At intervals of approximately $3 \mathrm{~min}$, the resistance was changed using the rheostats. The resistance values were $0.55,8.8,11,12.1,15.4,48$ and $\infty$ Ohms. During the long-term test, all parameters were recorded for three hours for specific resistance value. This test was performed on the resistance values of 15.4 and $48 \mathrm{Ohms}$. This test allowed for the estimation of the trend of module temperature during normal operation and to evaluate all parameters in the plateau region (once the temperature had reached a stable value).

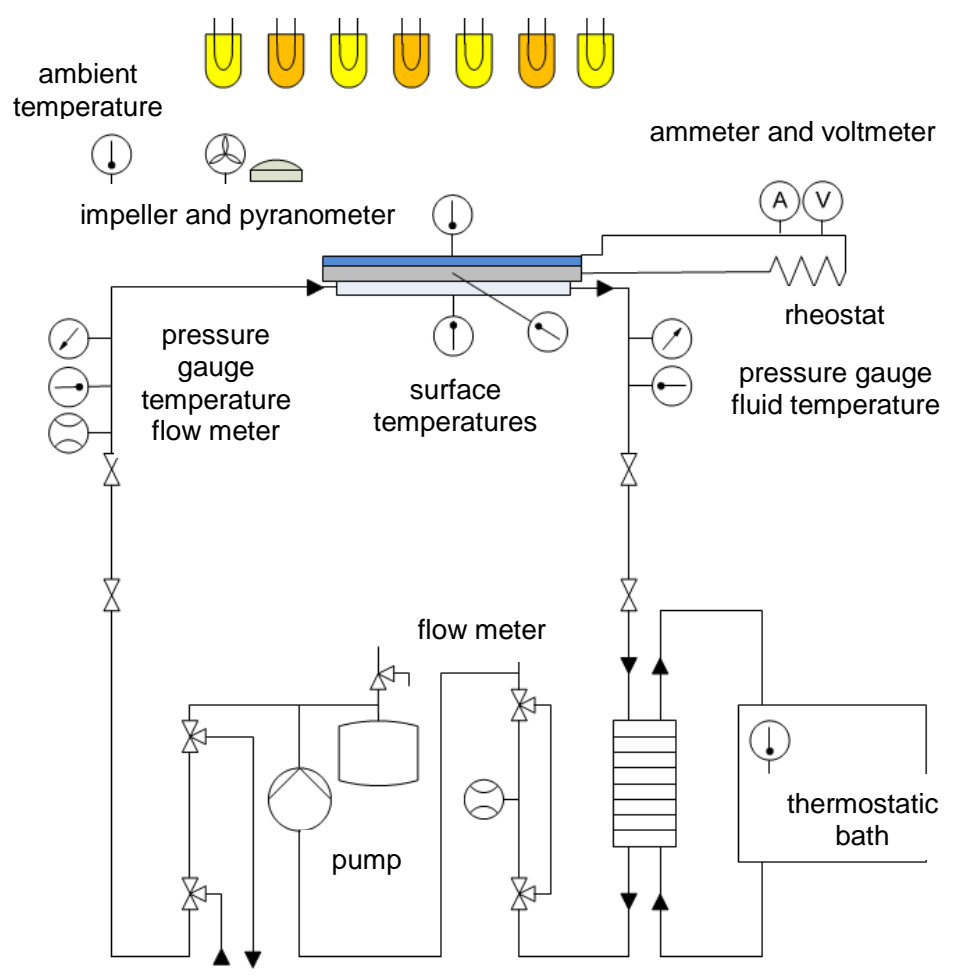

Figure 4 Measurement stand principal scheme [12].

\section{RESULTS AND DISCUSSION}

Maximum-power-point test

In the maximum-power-point test (see Table 3) the temperatures measured in different locations on the PV panel were different. The main reason for the temperature variation was the non-uniform irradiation of the module. The second reason was that the fibres were placed non-uniformly. For example, in the area of the panel electric box, cooling was low because fibres were in poor contact with the surface. The more the module was cooled, the more pronounced this effect was.

Furthermore, there was a small difference between the temperature in the thermostatic bath and the temperature in the inlet/outlet of the module. As was expected, the temperature difference between the inlet and outlet was higher for lower cooling. This was due to the greater driving temperature difference between the coolant and PV panel.

The surface temperatures on top of the panel were slightly lower than those on the bottom (the maximum difference was of $2.6^{\circ} \mathrm{C}$ ). Although the cooling effect was high enough in all cases and caused a significant reduction of the average panel temperature, the temperature of the coolant water had a small influence on cooling.

Figure 6 shows that cooling leads to a significantly greater peak of electrical power output. By cooling, the maximum power point is shifted to the right, reaching the maximum only at a higher voltage. At low voltages, cooling does not influence the resulting output or has only a minor influence on it. 


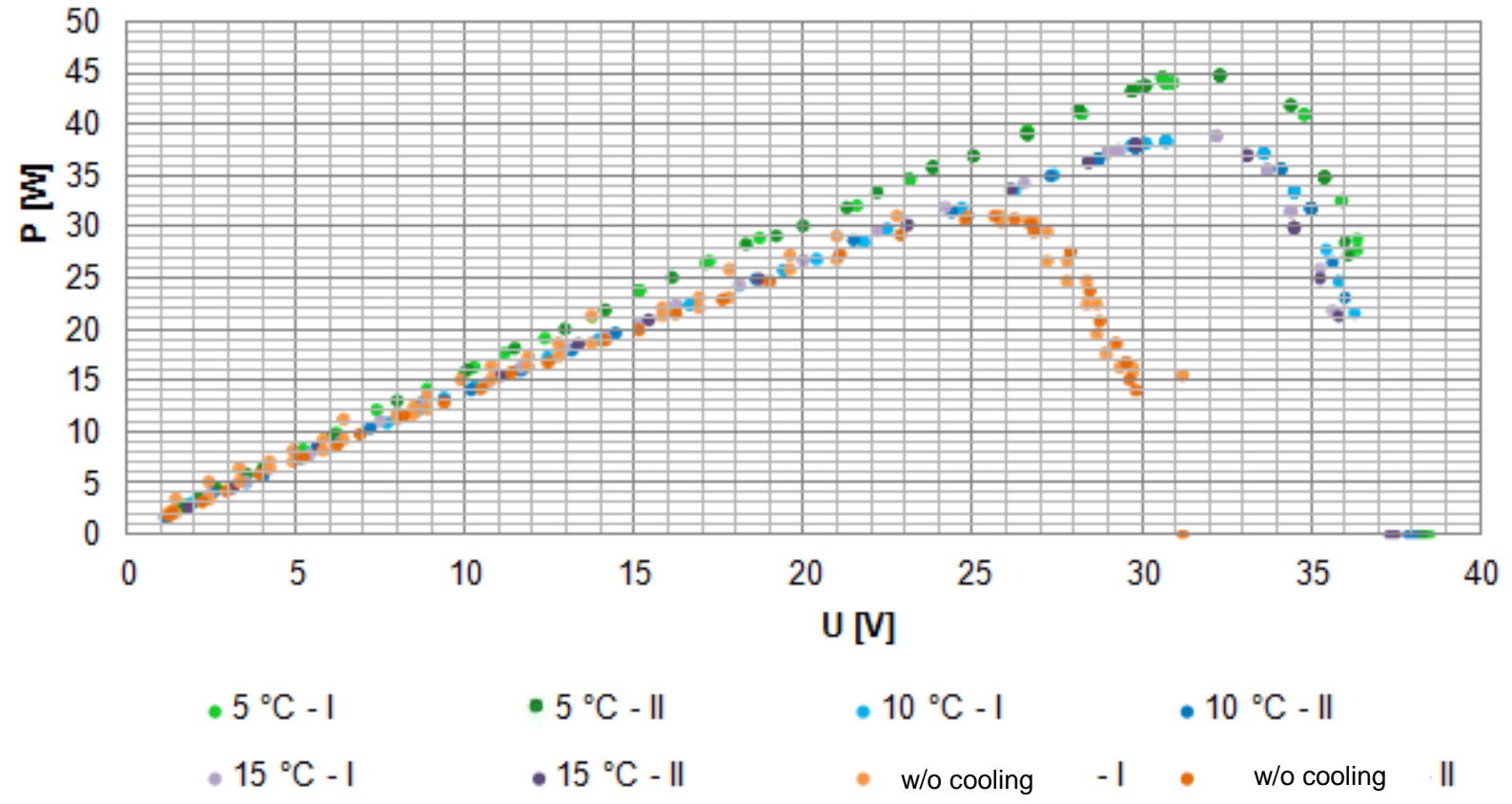

Figure 6 Maximum-Power-Point test. Electric output of PV panel vs temperature of cooling water [12].

Whether the module is cooled with water at temperature of $10^{\circ} \mathrm{C}$ or $15^{\circ} \mathrm{C}$, the cooling effect is irrelevant. Without cooling, a maximum power of $31.2 \mathrm{~W}$ was achieved. This value significantly differs from the manufacturer's specified nominal output of $110 \mathrm{~W}$. Besides the fact that the test stand cannot meet the standard test conditions, the aging of the module must be noted as a reason for this. However an increase in the maximum power output by up to $44 \%$ to $44.8 \mathrm{~W}$ can be achieved by means of cooling.

\section{Resistance test}

To evaluate the influence of resistance, six resistances were tested. The inlet/outlet coolant temperatures of the resistance tests were close to the corresponding temperatures at the maximum power point test. The results of the resistance test showed similar trends as the results of the maximum-powerpoint test. However, the module temperatures were slightly lower (about $1{ }^{\circ} \mathrm{C}$ ) in the resistance test. Since the parameters measured in the resistance test included only a few selected resistance values, the effect of cooling is pronounced only for $48 \mathrm{Ohms}$ of resistance. It was confirmed that the cooling significantly affects output only for resistances near the maximum power point.

\section{Long-time test}

Firstly the long-term test was carried out at a resistance of 15.4 Ohms and then it was repeated at a resistance value of $48 \mathrm{Ohms}$. For the 15.4-Ohm resistance there was no significant influence of cooling on voltage, current and power. These parameters were stable during the three hour test even when the temperature increased from $45{ }^{\circ} \mathrm{C}$ to $90{ }^{\circ} \mathrm{C}$. This result agreed with the results of the resistance test.
The opposite was observed for the long-time test with a resistance of $48 \mathrm{Ohms}$ (see Figure 7). Although the inlet/outlet coolant temperatures and module temperatures were very similar as for the $15.4 \mathrm{Ohms}$ resistance, the influence of cooling on electrical performance was pronounced. Substituting the performance of the uncooled module equal to $100 \%$, we achieved a performance increase of over $50 \%$. During the three hour experiment the temperature of the module mostly achieved its asymptotic value of $95^{\circ} \mathrm{C}$. The significant improvement in the performance due to the cooling is again apparent.

Table 3 Results of the Maximum-Power-Point test

\begin{tabular}{ccccc}
\hline & $\begin{array}{c}\text { strong } \\
\text { cooling }\end{array}$ & $\begin{array}{c}\text { medium } \\
\text { cooling }\end{array}$ & $\begin{array}{c}\text { weak } \\
\text { cooling }\end{array}$ & $\begin{array}{c}\text { no } \\
\text { cooling }\end{array}$ \\
\hline $\begin{array}{c}\text { temperature on top } \\
\text { of the module, }\left[{ }^{\circ} \mathrm{C}\right]\end{array}$ & 50.2 & 52.0 & 55.5 & 90.8 \\
$\begin{array}{c}\text { temperature under } \\
\text { the module, }\left[{ }^{\circ} \mathrm{C}\right]\end{array}$ & 52.6 & 52.6 & 55.6 & 89.7 \\
inlet temp., $\left[{ }^{\circ} \mathrm{C}\right]$ & 8.6 & 12.5 & 17.0 & - \\
outlet temp., $\left[{ }^{\circ} \mathrm{C}\right]$ & 12.1 & 15.3 & 19.3 & - \\
flow rate $[1 / \mathrm{min}]$ & 4.04 & 4.53 & 4.74 & - \\
pressure drop [bar] & 0.42 & 0.41 & 0.38 & - \\
max. electrical & 44.8 & 38.1 & 38.6 & 31.2 \\
power, [W] & & & & \\
heat flow, [W] & 1011 & 895 & 776 & - \\
\hline
\end{tabular}




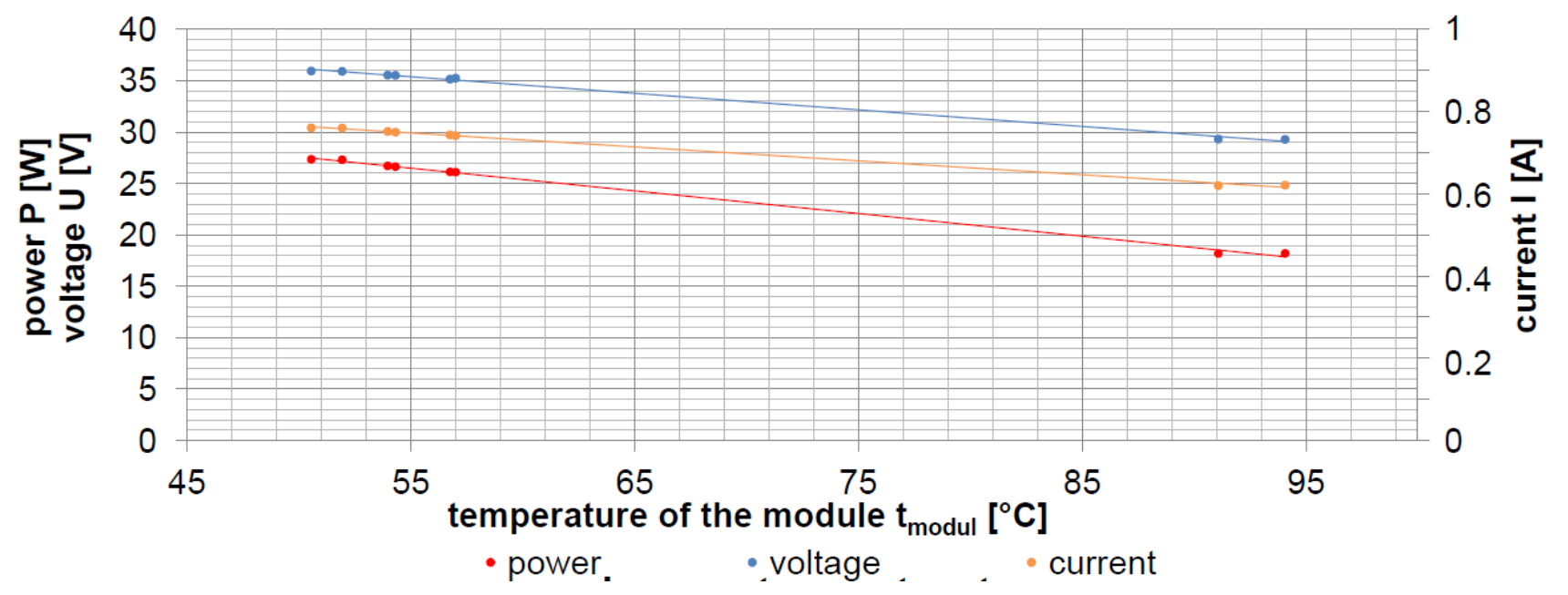

Figure 7 Long-Time test. Electric output, voltage and current vs average temperature [12].

\section{CONCLUSION}

All of the tests showed that cooling the module improves its efficiency. The mean efficiency increase is about $50 \%$ and it is expected that it can be even more for high-efficiency modules. The investigation of new commercially available photovoltaic modules could show how high the appropriate additional income would be. On the other hand, this increases the cost and requires energy to operate the pump in the hydraulic circuit of the coolant. These efforts are particularly advantageous in a limited space because the electrical power generated per square meter increases and thermal energy can be produced without the installation of additional devices.

Although cooling of PV panel with hollow fibres is feasible (up to $1 \mathrm{~kW}$ of heat can be removed by cooling system reducing the module temperature from to about $50^{\circ} \mathrm{C}$ ) further research is still required. It is associated with both economic reasonability and durability of the fibre cooling system.

The approach using the fibres with feeders was not reliable enough and should be reconsidered. Overall, the durability of polypropylene fibres is still questionable, and the possible application of more resistant kinds of plastic, such as polyamide, would be reasonable. The experimental results have shown how quickly an uncooled or insufficiently cooled photovoltaic module reaches temperatures that are quite close to the temperature at which polypropylene loses its mechanical strength.

\section{ACKNOWLEDGEMENT}

The research in the presented paper has been supported by the project LO1202 and the project No. CZ. 1.07/2.3.00/20.0188, HEATEAM - Multidisciplinary Team for Research and Development of Heat Processes, with financial support of the MEYS under the programme NPU I.

\section{REFERENCES}

[1] REN21's Renewables Global Status Report. http://www.ren21.net/ren21 activities/globalstatusreport.aspx.

Retrieved 2014-11-06.
[2] Pathak M. J. M., Sanders P. G., and Pearce J. M., Optimizing limited solar roof access by exergy analysis of solar thermal, photovoltaic, and hybrid photovoltaic thermal systems, Applied Energy, vol. 120, 2014, pp. 115-124.

[3] Akbarzadeh A., Wadowski T., Heat pipe-based cooling systems for photovoltaic cells under concentrated solar radiation. Appl. Therm. Eng. 1996, vol. 16, pp.81-87.

[4] Chaniotakis E., Modelling and analysis of water cooled photovoltaics, M.Sc. thesis, Faculty of Energy System and Environment, Department of Mechanical Engineering, University of Strathclyde, Glasgow, Scotland, 2001.

[5] Moharram K.A., Abd-Elhady M.S., Kandil H.A., El-Sherif H., Enhancing the performance of photovoltaic panels by water cooling, Ain Shams Engineering Journal, 2013, vol. 4, pp. 869-877.

[6] Ibrahim A., Othman M., Ruslan M.H., Mat S., Sopian K., Recent advances in flat plate photovoltaic/thermal (PV/T) solar collectors, Renew Sustain Energy Rev., vol. 15, 2011, pp. 352-365.

[7] Teo H.G., Lee P.S., Hawlader M.N.A., An active cooling system for photovoltaic modules, Applied Energy, vol. 90, 2011, pp. 309315

[8] Zarkadas D. M., Sirkar K. K., Polymeric hollow fiber heat exchangers: An alternative for lower temperature applications, Ind. Eng. Chem. Res., 2004, vol. 43, pp. 8093-8106.

[9] Astrouski I., Raudensky M., The study of polymeric hollow fibre heat exchangers, Proc. of the 18th Inter. Conf. Engineering mechanics, Svratka, 2012, pp. 47-57.

[10] Hallmark B., Hornung C.H., Broady D., Price-Kuehne C., Mackley M.R. The application of plastic microcapillary films for fast transient micro-heat exchange, International Journal of Heat and MassTransfer, 2008, vol. 51, pp. 5344-5358.

[11] Dorfling C., Hornung C.H., Hallmark B., Beaumont R.J.J., Fovargue H., Mackley M.R. The experimental response and modelling of a solar heat collector fabricated from plastic microcapillary films, Sol. Energy Mater Sol. Cells 2010;94:1207e21.

[12] Schmidt M., Leistungsoptimierung eines Photovoltaikmoduls durch Kühlung mittels Kunststoffhohlfaserwärmeübertrager, Masterarbeit, Fakultät für Maschinenbau und Verfahrenstechnik, Hochschule Augsburg, Germany, 2014. 